\title{
Body measurement and automobile design
}

by M. Matsuno, NISSAN motor Co.

\section{人体計測と自動車の設計}

\section{1.まえがき}

自動車の設計にあたり，人間工学上まず必要なことは 人体の計測值である。すなわち, 人体の計测值データ と, 自動車において人間のタッチする全ての部位の寸法 などを検討整理しこの両者間の optimum machine point を見い出すことが重要な仕事となるわけである。 さて, 人体計測值であるが, 各国において数多くのデー タが発表されており，とくにアメリカの空軍で行なった 4060名, 132 項目の計測データは有名である。この測定 法は詳細に定められており, 統計処理も, Mear, Standand deviation, Variance, Percentile value について示さ れている。これに対してわが国でも航空医学実験隊にお いてパイロット239名, 62項目について詳細に調査され ている。なお，その他にアメリカでは Henry Drefuss

の The measure of manが有名である。これらのほか に多種多様のデータが発表されているが，さてこれらの 計測值を利用する段になると，

1）白人（少なくともアメリカ人）および日本人の成 人男女の各測定項目毎に整理された統一的な統計表 示がないので，撰択に迷らこと。

2) 自動車の設計に際し, 実際に必要となるデータに
日産自動車KK実験課 松 野 正 徳

\section{そしいこと。}

などがあげられる。自動車技術会人間工学研究委員会 では，これの打開の必要性を痛感し、昨年10月.新たに人 体計測分科会が，東京大学大島正光教授を中心に発足， 活動を開始している。

\section{2. 自動車設計に $3 \mathrm{DM}$ を採用}

人体計測值が必要となるのは, 設計段階から試作, 完 成に至るすべての時期にわたるのであるが，設計段階に おいて特に必要となるのは 2 DM(Two dimenional manikin) である。このマネキンの正確なものの製作には かなりの努力を必要とする。たとえば H-point の位置, 腕の幅, 着座時の大腿部や下腿部の幅などの数值が不十 分なためである。そのためには他の既知の dimenfson を比例計算などにより求めてゆかなければならない。モ ックアップ段階や完成試作車の段階の测定には，3 DM (Three dimensional manikim) が用いられる。当社では S A F で定めたものを使用している(第1図)。これはア メリカ人の成人男子体重 50 , 身長 90 th percentile のも のである。これを被検車内に着座させ, シートのたわみ 量, 角度, legrocm の dimension, head clearance など を測定する。身長を90th percentile にしたのは, leg rocm などの測定に大は小を兼ねるためかと思われる。 


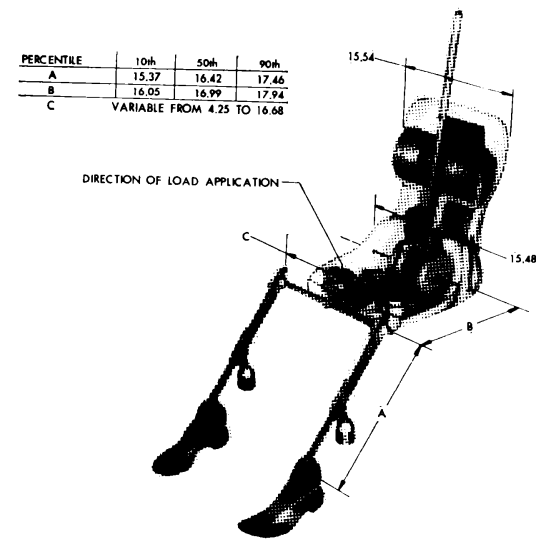

第 1 図 3 デメンション・マネキン

このSAFの 3 DMがつくられ, 全米のメーカーが使用 しはじめたのは, SAF Aerospace automotive draw. ing standard で Car and body measuring procedure $と$ して定められた 1963 年 9 月以降である。それ以前には Ford 社では「フオード・オスカー」を, Chrysler 社は A-point machine, Fisher Body 社は "Fisher Saddle machine”などと各社各様に使用していた。このためデー タ相互の比較検討に困難を来たしたためで,このS A F の $3 \mathrm{DM}$ の出現によって設計の手順が革命的に変りつつ あるのではないかと思われる。

従来, 自動車の設計に際して, まずェンジン部が決定 され，次にそれを塔載するシャーシを決定，ついでボデ イを被せ，最後の人間が内部空間にギゴチなく押込めら れるといら順序であったのであるが，前述の car ard body measuring procedure 沬その測定の原点を, S A F は $3 \mathrm{DA}=\mathrm{H}$-point に定め, その原点からすべてのdimension が定められてゆく順序になっている。つまり旧

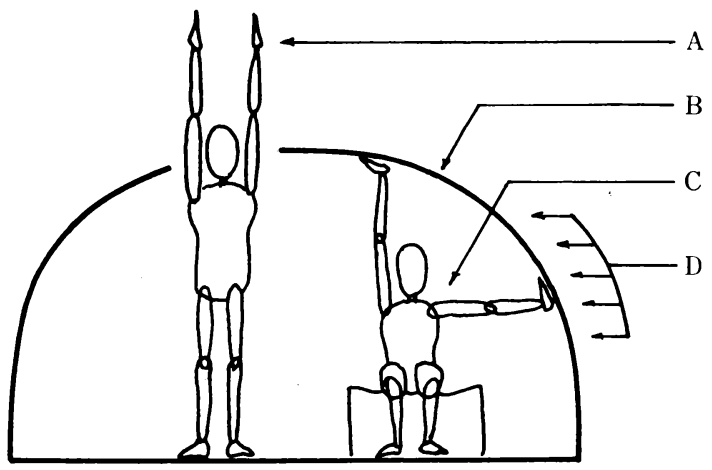

第 2 图 Compartment 内部の自由度 の基本的な 4 つの Factor
来の方式を求心的デザインと評すれば， $3 \mathrm{DM}$ の出現は 人間尊重の遠心的設計といえよう。この点に人間工学的 に深い意義を感ずるのである。

この measuring procedure は153項目にのぼる dimension p degee を計測するのであるが, 当社で はこのらち必要と思われる約50項目と, 独自に約 100 項 目を新たに加光，測定を行なっているが，わが国でこの S A F の方式をそのまま採用してゆくか，また日本独自 のものを制定してゆくかは今後に残された大きな問題で はなかろらかと思われる。

\section{Compartment の自由度の考察}

さて, 自動車 Compartment 内の広さを検討する場合 にただ単に広い，または狭いと抽象的に表現するのでは なく何らかの定量的表現法がないだろらかといら問題で あるが、これは人体計測とともに大きな問題ではなかろ らかと思われる。すなわち, occupant の体格および posture と Compartment 内部の各部位 dimension との関 係が相互に関連するからである。

そこで，Compartment 内における自由度についての 基礎的な考方方を考察してみた。すなわち，Compart$\mathrm{m}$ tnt 内部自由度の基本的な factor をつぎの 4 種に区分 した。（第 2 図）

Factor A………人体の自由度の Maximum 值よ おび Minimum を定める factor

Factor B …….... Roomness（部屋の広さ）のと り方の factor

Facto C…………室内でとる人体の posture（姿 勢）の factor

Factor D…………と他の条件

まず，Facfor Aについては，自由度を考える場合の 人体の Maximum および minmum の posture を高 さ(H), 長さ(L), 幅(以)にわけ, さらにモデュールの考えを 導入して，第 1 表のような分類を行なってみた。

つぎに Factor Bについては, Compartment の側のdimension を前後席について side view の長さ(L)を定め てみた。高さおよび幅は省略したが，今後定める予定で ある(第 3 図)。Factor Cは Compartment 内における 姿勢の区分である。すなわち，

総体的な姿勢を，C-1-1 正規姿勢， C-1-2 p やくずれた姿勢, C-1-3ひどいくずれ姿勢, C-14 アクロバット姿勢の 4 つに区分，C-2 リクライニン グ状態（床面と上体の角度）を $90 \sim 100^{\circ} ， 101 \sim 110^{\circ}$, $111 \sim 120^{\circ}, \quad 121 \sim 130^{\circ}, \quad 131 \sim 140^{\circ}, \quad 141 \sim 150^{\circ}, \quad 151 \sim$ $160^{\circ}, \quad 161 \sim 170^{\circ}, \quad 171 \sim 180^{\circ}$, の 9 つに分, C-3 肘の状態は. 1)アームレスト上と.2)空より出すの $2 つ$ に, C- 4 脚の状態を脚揃え, 脚開き, 脚組み, シート 上に座るの 4 つにそれぞれ区分してみた。 
第 1 表 A Factor A

A-H 人体の自由度のMaximum 值, Minimum 值の高さ(h)に関する facfor

$\mathrm{A}-\mathrm{H}-1$

$\operatorname{Max}(100 \%)$ 值

\section{$\mathrm{A}-\mathrm{H}-2$}

Min (100\%) 值
A.H.1.1

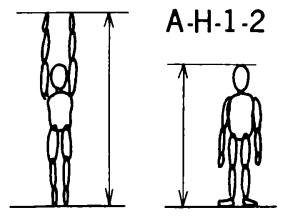

A.H.1 -3

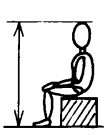

A.H.1.4

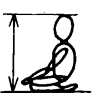

A.H.1.5

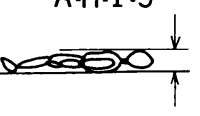

A.H.2.1

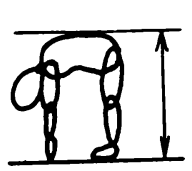

A.H.2.2

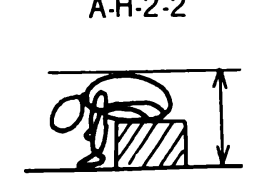

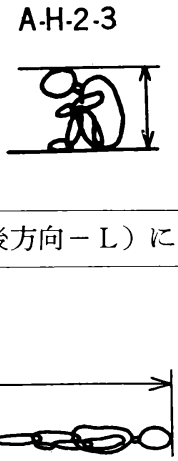

A.L.1 2

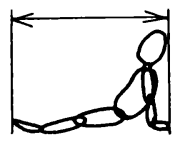

A.L.1.3
A.H.2.5

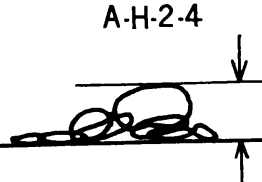

A.H.2.5

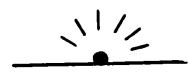

\section{A-L 值人体の自由度のMaximum值, M nimumの長さ（前後方向－L）に関する Factor}

\section{A-L-I}

$\operatorname{Max}(100 \%)$ 佃
A.L.1-1

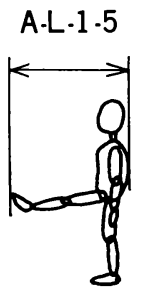

A.L.1-6 ,

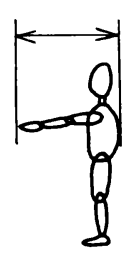

A.L.1-7

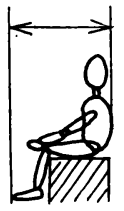

M-L-2

Min (100\%) 值

A.L.2-3

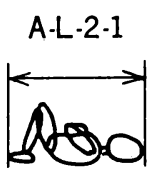

A-L.2.2

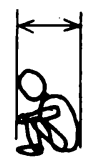

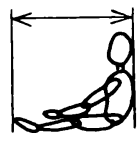

A.L.1.4 
第 1 表B Factor A

A-W 人体の自由度の Maximum 值, Minimum 值の幅（左右方向-W) 関にする factor

$\mathrm{A}-\mathrm{W}-1$

$\operatorname{Max}$ 值 $(100 \%)$

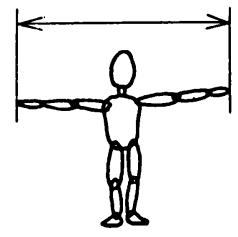

A-W.1-2

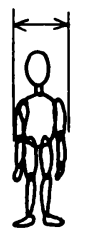

A.W.1.3

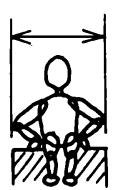

A.W-1.4

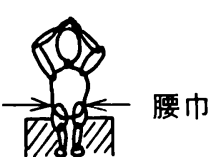

A-W-2

Min值（100\%）

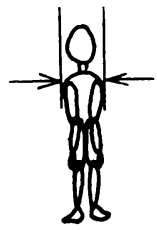

A.W.2-2

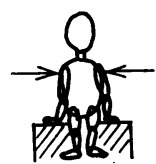

A.W.2-2

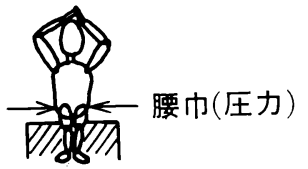

A-W. 2.3

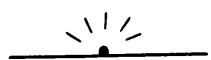

A-M モデュロール (mcdulor)

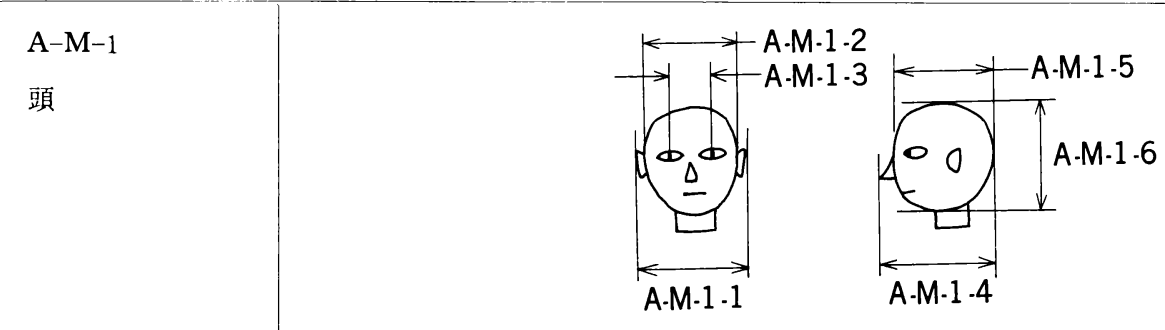

A-M-2

軀 幹

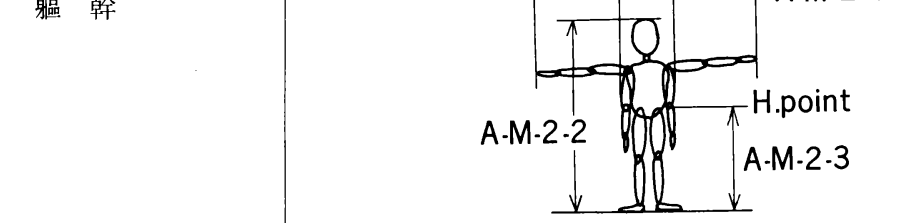

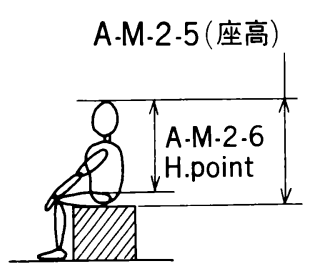

\section{A-M-3}

手・足
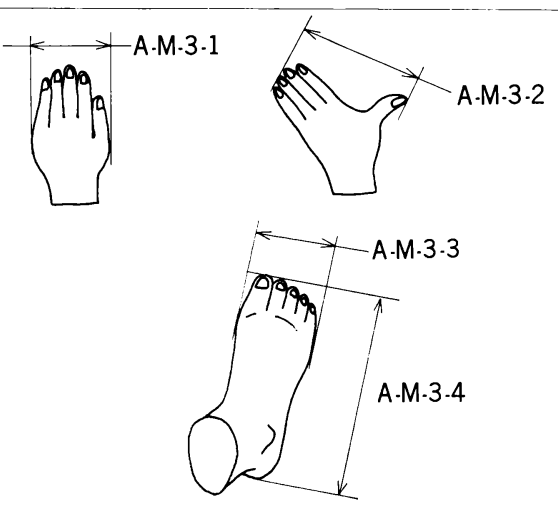


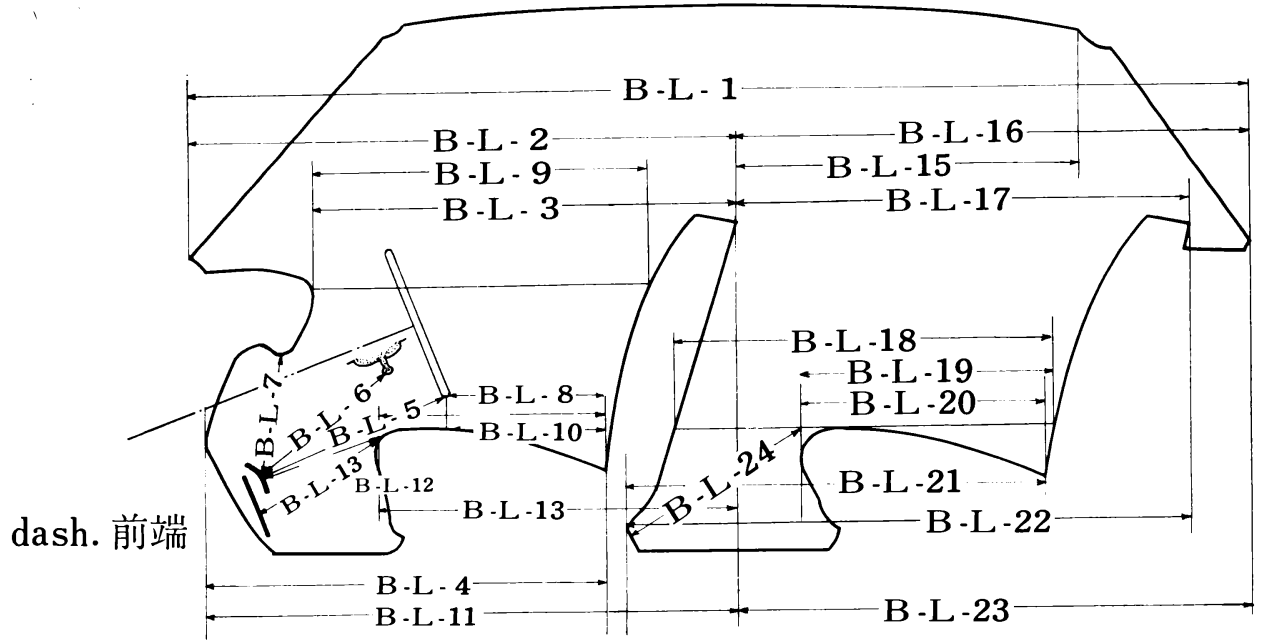

第 3 図 Compartment 内部の前後席の長さ

また，Factor Dすなわち，上記では区分し得ない各 種の条件をつぎのように区分してみた。

$\mathrm{D}$ - 1 車（全体的状態）

D-1-1 停車中 (parking), D-1-2 走行中 (driving)

D-1-3 水平面に対する車の角度

$\mathrm{D}-2$ 座席

$\mathrm{D}-2-1$ 前席 (front) $\mathrm{D}-2-2$ 後席 (rear） D 2-3 第 3 席 (third), D-2-4 右席 (right), D-2-5 左席 (left), $\mathrm{D}-2-6$ 中央 (denten) $\mathrm{D}-2-7$ fron seat slide ……. fore most, $\mathrm{D}-2-8$ 同.....neutral $\mathrm{D}-2-9$ 同…...rear most, D-2-10 同......fore maot $上$ り ( ) $\mathrm{mm}, \mathrm{D}-2-11$ bench $\mathrm{D}-2-12 \mathrm{se}-$ parate 型, D- $2-13$ backett 型, D-2-14 安 全ベルト有，D-2-15安全ベルト無

$\mathrm{D}$-3 乗員数

$\mathrm{D}-3-1$ 1名, $\mathrm{D}-3-2$ 2名, $\mathrm{D}-3-3$

3 名, $\mathrm{D}-3-4$ 名, $\mathrm{D}-3-5$ 名, $\mathrm{D}-$ $3-6 \quad 6$ 名

$\mathrm{D}-4$ 被検者

$\mathrm{D}-4-1$ 性, $\mathrm{D}-4-2$ 年令, $\mathrm{D}-4-3$

身長, $\mathrm{D}-4-4$ 体重, $\mathrm{D}-4-5$ 民族

$\mathrm{D}-5$ 被検者の服装

$\mathrm{D}-5-1$ 裸, $\mathrm{D}-5-2$ 極<軽装, $\mathrm{D}-5$ -

3 軽装, $\mathrm{D}-5-4$ 正装, D 5-5 重装,

$\mathrm{D}$-6 被検者の体位

自動車のXY 2 軸に対する人体の X Y 2 軸の相対角 度

$\mathrm{D}-7$ 環境条件
D-7-1 道路状況, $\mathrm{D}-7-2$ 天候気象, D-8 3 way（前後, 左右, 上下)

単純に 3 方向それぞれの自由度を論ずる場合

D-9 3 dimension 球状

人体の最大スパンを直径とする球。

$$
=\text { ニュース }=
$$

\section{産工試に人間工学課設置}

工業技術院産業工芸試験所意匠第 1 部機能分析課が, 昭和 41 年 4 月 1 日付をもって, 人間工学課と改称し, デ ザイン分野における人間工学研究を一層強力に押しすす めることになった。

なお，同課長には意匠第 1 部長知久篤氏が当分の間兼 務する。

\section{真辺理事に照明学会賞}

本学会理事真辺春雄氏（大阪大学教盖学部教授）は, このほど「工場オフィスの照明」を出版したが，これを 機会に, 照明学会より昭和 41 年度照明学会賞が授与され ることになった。 


\section{Aviation accidents and ergonomics}

(A conversazione).

- M. Oshima, F. Motobayashi, H. Araki, M, Sanuki, N,Takagi, H.Kimura S. Izumi, S. Yokobori and K.Suwa.-

Preventive measures against aeroplane accidents were discussed from ergonomics viewpoints. Personal conditions of the pilot, fatigue, incapabilities to follow the operation characteristics or acute disturbances in vision and space perception were mentioned as posible human error factors in aviation. Interaction of human operations with the reliability of the discussion, as human operations seemed not to be excluded in any aviation techniques. Studies on physiological or psychological factors related to aviation accidents were referred and safety allowances for aerodrome facilities were pointed out to be the most necessary. Impoved displays around the cockpit and the automatic landing system should be developed, taking into account the psychological factors as response delay, misjudgement or limitations of human control capacities.

\section{Some ergonomics aspects of the control system of the YS-11 plane.}

by, Y. Nagasawa and N. Hirashima

Ergonomics aspects of the Japanese turbo-prop aeroplane YS - 11 were discussed. General arrangement of interior spaces, noise protection for crew and passengers and air conditioning were appreciated. Other merits might be the systematic layout of auxiliary controls making efficient use of the overhead panel, though the panel was a little too large, and considerations as to grouping, form and colour of main controls. Arrangement of turn and bank indicators, which were set at the right of the chief pilot and at the left of the second pilot, should be improved. 72 signal lamps, $40 \%$ of which were located on the overhead panel, were not effectively grouped and adoption of a concentrated warning-lamp system with masterlamps in the middle of visual field, along with the reduction of the mumber of lamps, was also recommended.

\section{Ergonomics study group : Aeromedical Laboratory of Defence Air Forces.} by $\mathrm{S}$. Yokobori

Aeromedical Laboratory of Defence Air Forces, Tachikawa in west Tokyo, was introduced. As the national center of the aeromedical research in Japan. the laboratory is mainly concerned with pilots' fitness environmental and ergonomic aspects of the aviation and physiological stress of the pilot.

\section{Approach to ergonomics by predetemined Time Standard. \\ by K. Ikenaga.}

Predetermined Time Standard was explained and discussed as one of reliable ergonomic research techniques in evaluating the motion time of any operation. Work factors for various kinds of operations were summarized in tables. The possibility of using the work factors for mental processes was also discussed.

\section{Work study, and it' application to ergo- nomics II.}

by K. Tsubouchi.

As the second part of the series, micromotion study and memomotion study techniques by means of 8 or $16 \mathrm{~mm}$ films were demonstrated, $8 \mathrm{~mm}$ cinecamera technique developed at Waseda Univ. was introduced.

\section{Body measurement and automobile desgin.} by M. Matsuno.

Use of S. A. F 3-dimensional manikin for interior design of automobiles was recommended. Fundamental factors for compartfment design may be classified as the following: Factor $\mathrm{A}$ as determinant of the maximum and the minimum or degrees of freedom of body sizes, Factor B concerned with roomness, Factor C related to the posture, and Factor D including other dimenisonal and environmental factors.

\section{Analysis of the man-tiller system.}

by K. Tsubouchi.

A Japanese tiller operated by a walking farmer was studies ergonomically. Gear and main clutch levers were revealed to be located too far from the operator.

The clutch lever attached to the handle-bar should also be improved. Heart rate of the trained operators during the straight driving of the tiller was about $90-100$ beats $/ \mathrm{min}$. Heart rate increase was more conspicuous in turning the machine, as the operator had to lift the handle-bars to let the rotating plough free from the ground. Variation of flicker fusion frequency was tmall, but arm tremor became large after the tillege. Noise. level during the operation was as high as 90-93 phones. Varioues. types of tillers were compared and thier improvement especially as to the turning operation was discussed.

\section{Instruments for ergonomic studies.} by K. Kogi.

Instruments for the study of physiological and psychological reactions which may be applied for ergonomic research were introbuced with thier makers' names. 